\title{
SCHIZOPHRENIC PUBLIC ADMINISTRATION REFORM IN HUNGARY TENSION BETWEEN ANTI-NPM SYSTEMIC AND PRO- NPM ORGANIZATIONAL REFORMS
}

\author{
MILKÓS ROSTA ${ }^{1}$ \\ ${ }^{1}$ Lecturer, Department of Comparative Economics, Corvinus University of Budapest \\ E-mail:miklos.rosta@uni-corvinus.hu
}

\begin{abstract}
The aim of the paper is to highlight the main characteristics of the recent Hungarian public administration reform, as well as to reveal the inconsistent nature of some of its element and to describe the connected risks. The starting point of the article is the Magyary Zoltán public administration development programme. The reform steps are compared to the ideal type NPM approach. The Hungarian public administration reform can be characterized by strong centralization and the revitalization of Hungarian anti-liberal traditions at macro level, and by the support of the enhancement of market rules and management at micro level.
\end{abstract}

Keywords: new public management, Hungarian public administration reform, Magyary Zoltán public administration development programme, centralization

JEL-code: H11, H38, D73

\section{Introduction}

The aim of the paper is to describe the main characteristics of the Hungarian public administration reform that has been implemented since 2010, as well as to highlight the inconsistent nature of some of its elements, and to discuss the connected risks. The starting point of the study is the Magyary Zoltán Public Administration Development Programme, containing the reforms and principles of the public administration system to be introduced by the conservative government formed in 2010. In order to highlight the main characteristics of the Magyary Programme the methodology of comparison was applied; the recommendations of the Magyary Programme are compared with the principle and guidance of the ideal type new public management (NPM) approach.

Based on the academic literature, the first section offers a brief overview of the ideal type NPM approach. The following section covers the relationship between NPM and the Magyary Programme: we shall focus on the four areas of intervention of the programme and examine whether or not specific points of the programme are compatible with NPM. Every area of 
intervention is analyzed separately, but special attention is paid to the restructuring of public administration, since this area of intervention of the Magyary Programme has already been implemented and resulted in a significant change in the Hungarian public administration system.

To show the relevance of our research, a brief detour on the impact of the 2007/8 economic crisis on the NPM movement seems in order because the very relevance of NPM was seriously challenged in its wake (Arellano-Gault 2010; Bao - Wang - Larsen - Morgan 2013; Lapsley 2009; Peters - Pierre - Randma-Liv 2011; Siltala 2013). In our view, the setback suffered by the NPM philosophy is ephemeral because the transaction costs of government intervention and bureaucratic management will likely exceed the level that governments will be able to finance already in the short run. Various NPM proposals calling for market mechanisms in public administration that already determine the NPM practice in Anglo-Saxon countries will again gain prominence in democracies with a capitalist system after the crisis is over. If applied in a manner that is congruent with the social and natural environment, as well as with institutional and cultural milieu, the NPM-inspired management tools will be able to stop the pendulum that now swings towards bureaucratic coordination and revert it to economic rationality and market mechanism. This will call for a re-assessment of the government's role, which will again clear the path for a conservative/liberal economic policy that has strong ties with the NPM movement and stands in stark contrast with the economic policies currently pursued in several countries. Hopefully, the backlash will not be too great and economic actors will learn from the mistakes of the past: a well-functioning, efficient government capable of handling market failures, the freedom of private property and the unique efficiency and innovativeness of market mechanisms are all necessary for a sustainable development. ${ }^{1}$

If the above scenario is correct, the NPM philosophy will continue to play a decisive role in the economic policy of developed countries, and it is therefore relevant to examine how the NPM philosophy is reflected in the Magyary Programme, the strategic public administration development plan of the current conservative Hungarian government. ${ }^{2}$

1 According to Lapsley (2010: 19), "NPM is not dead. The current global financial collapse intensifies the importance of NPM to reforming governments. This financial crisis underlines the significance of NPM for the next decade, at least". See also Haynes (2011).

2 The article does not intend to deliver an opinion on the NPM approach; it is merely used as a tool for comparison, based on which the internal contradictions of the Hungarian public administration reform can be 
The relevance of the article is strengthened by the fact that only a few scientific articles have analyzed the so-called "unorthodox" reform steps of the conservative Hungarian government, in the course of which the Hungarian government intends to take an unconventional path in public administration restructuring, as well as in economic and social policy. (Lengyel - Ilonszki, 2012). The government - not completely unrealistically - is confident that other countries, primarily Central-Eastern European countries, will follow this path. The Hungarian public administration reform can be characterized by strong centralization ${ }^{3}$, the strengthening of the state's role and the revitalization of the Hungarian anti-liberal, etatist traditions at macro level, and - especially for communication purposes - by the support of the enhancement of market rules and management at micro level.

\section{New Public Management, definition, instruments and their categorization}

This section is devoted to the creation of an acceptable interpretative framework. First, we shall define the NPM movement. The concept of NPM has been repeatedly addressed by the scientific community, but none of the proposed definitions have become generally accepted. (Bornis 2002; OECD 1995; Van de Walle - Hammerschmid 2011)

In the present study, NPM is defined as the public management movement, which set out to radically improve of the public sector efficiency and determined the public administration reforms in the Anglo-Saxon countries from the early 1980s and in the Western and Northern European countries from the early 1990s (Kuhlmann 2010). NPM is theoretically well grounded in management sciences and new institutional economics, specifically in public choice theory, transaction cost economics and principal-agent theory (Barzelay 2001; Borins 2002; Boston

discussed. The ideal type NPM approach is suitable for this, because its basic principles are clear and unambiguous for public management experts - in spite of the debates on NPM. The information provided in the article is also relevant for those who oppose the NPM approach and for those who believe that this approach will fade away. However, based on the above it is obvious that the author expects NPM to gain in importance in the future.

3 By centralization, we mean a change that affects the decision-making, control and instruction competencies, partially or wholly transferring them to an upper level of the administrative hierarchy (Hutchcroft 2001; Pollitt - Bouckaert 2011:104). 
2011; Grüning 2001). The improvement of the efficiency of the public sector is envisioned through the use of stronger market mechanisms (e.g. privatization, outsourcing, PPP, contracting out) (Greve - Hodge 2011; Pallesen 2011; Walker - Brewer - Boyne - Avellaneda 2011), decentralization and structural reorganisation (e.g. through the decentralization of the execution of tasks via semi-autonomous organizations, separation of provision and production and separation of politics and administration as well) (Box - Marshall - Reed - Reed 2001; Manning 2001; Moynihan 2006; Pollitt 2005), the introduction of accounting and management innovations (e.g., performance assessment, accrual accounting) (Hood 2007; Pollitt 2002) and the application of other management techniques used in the private sector (Bach - Bordogna 2011; Van der Walle - Hammerschmied 2011). From the 1990s onward, there has been a growing emphasis on citizens' needs and demands: the involvement of citizens in community decisions (i.e. customer orientation and the support of an active citizenry) became one of the movement's priorities. ${ }^{4}$

After defining the NPM, we shall briefly review the diverse instruments employed by NPM, based on two key studies. Hood's (1991) seminal study is one of the key texts in NPM studies. Most instruments lumped together under NPM are generally categorized according to his doctrines.

Table 1 shows that all NPM instruments can be assigned to one or another of Hood's seven doctrines of NPM and, also, that these components are rational, consistent and form a coherent whole.

Table 1. Hood's doctrines and the NPM instruments

\begin{tabular}{|l|l|l|}
\hline No. & \multicolumn{1}{|c|}{ Doctrine } & \multicolumn{1}{|c|}{ Instrument } \\
\hline 1 & $\begin{array}{l}\text { 'Hands-on professional management' in the } \\
\text { public sector }\end{array}$ & $\begin{array}{l}\text { HRM systems, strategic planning, } \\
\text { transformation of formal institutions } \\
\text { (e.g., regulation of the hiring and }\end{array}$ \\
\hline
\end{tabular}

As one can see, the NPM is a very diverse trend that can also be considered as an approach. In this article the Hungarian reforms are not compared with the NPM practice of a particular country but with the ideal type NPM approach. About NPM in general see also: Christensen - Laegreid (2002); Christensen - Lægreid (2011); McLaughlin - Osborne - Ferlie (2002); Ongaro (2009); Osborne - Gaebler (1992); Pollitt - Bouckaert (2011), Pollitt - van Thiel - Homburg (2007) and Zavattaro (2013). 


\begin{tabular}{|c|c|c|}
\hline & & dismissal of employees) \\
\hline 2 & $\begin{array}{l}\text { Explicit standards and measures of } \\
\text { performance }\end{array}$ & Balanced indicator system \\
\hline 3 & Greater emphasis on output controls & $\begin{array}{l}\text { Performance assessment systems, } \\
\text { performance-based pay }\end{array}$ \\
\hline 4 & $\begin{array}{l}\text { Shift to disaggregation of units in the public } \\
\text { sector }\end{array}$ & $\begin{array}{l}\text { Organizational restructuring: creation } \\
\text { of single-purpose organizations, } \\
\text { agencies, holdings, structural } \\
\text { reorganization within an organization }\end{array}$ \\
\hline 5 & $\begin{array}{l}\text { Shift to greater competition in the public } \\
\text { sector }\end{array}$ & $\begin{array}{l}\text { Outsourcing, contracting out, PPP, } \\
\text { service level contracts }\end{array}$ \\
\hline 6 & $\begin{array}{l}\text { Stress on private-sector styles } \\
\text { management practice }\end{array}$ & $\begin{array}{l}\text { Budget reforms, adoption of } \\
\text { accounting policies, greater } \\
\text { integration of IT, change management }\end{array}$ \\
\hline 7 & $\begin{array}{l}\text { Stress on greater discipline and parsimony in } \\
\text { resource use }\end{array}$ & $\begin{array}{l}\text { Accounting regulations, employment } \\
\text { of internal and external audit systems }\end{array}$ \\
\hline
\end{tabular}

Source: Hood (1991:4-5); Instrument column added by the author

Beside the categories set up by Hood (1991), the categories proposed by Schedler - Proeller (2002) which are based on their study of the NPM practices by the local governments of Continental European countries are also reviewed in order to better understand the NPM instruments.

Table 2. Generic element categories of NPM

\begin{tabular}{|l|c|c|}
\hline \multicolumn{1}{|c|}{ Category } & Characteristics/objectives & Examples \\
\hline Organisational restructuring & Decentralization & City managers \\
& Delegation of responsibility & Holding structure \\
& Reduction of hierarchy & Agencies \\
& Separation of political and & \\
& managerial roles & \\
\hline Management instruments & Output orientation & Performance agreements \\
\hline
\end{tabular}




\begin{tabular}{|c|c|c|}
\hline & $\begin{array}{c}\text { Entrepreneurship in public } \\
\text { administration } \\
\text { Efficiency }\end{array}$ & Performance-related pay \\
\hline Budgetary reforms & $\begin{array}{l}\text { Closer to private sector } \\
\text { financial instruments }\end{array}$ & $\begin{array}{c}\text { Cost accounting } \\
\text { Balance sheet } \\
\text { Accrual accounting }\end{array}$ \\
\hline Participation & Involvement of the citizen & $\begin{array}{l}\text { Neighbourhood councils } \\
\text { E-democracy } \\
\text { Co-operation with civil } \\
\text { organizations }\end{array}$ \\
\hline $\begin{array}{l}\text { Customer orientation } \\
\text { Quality management }\end{array}$ & $\begin{array}{c}\text { Gain legitimacy in service } \\
\text { delivery by improving } \\
\text { quality } \\
\text { Re-engineering }\end{array}$ & $\begin{array}{c}\text { One-stop shops } \\
\text { Service level agreements } \\
\text { E-government }\end{array}$ \\
\hline $\begin{array}{l}\text { Marketisation } \\
\text { Privatisation }\end{array}$ & $\begin{array}{l}\text { Reduction of public sector } \\
\text { Efficiency gains through } \\
\text { competition and market } \\
\text { coordination }\end{array}$ & $\begin{array}{c}\text { Privatisation } \\
\text { Contracting out } \\
\text { PPP } \\
\text { Public procurement }\end{array}$ \\
\hline
\end{tabular}

Source: Schedler - Proeller (2002:165), with the author's supplements

Table 2 shows the wide range of reform proposals made by NPM for improving the administrative system. The beauty of NPM lies exactly in its clear and multi-facetted theoretical grounding and its wide range of practical instruments. We may quote the metaphor by (Pollitt 1995:133) that NPM is basically a shopping basket in which the governments and experts of a particular country can simply select the reform proposals and managerial instruments that are best compatible with their country's culture. However, a shopping of this kind is not as simple as 
it might appear at first glance: the selected items have to fit the country's institutions and its administrative culture, as well as with each other. ${ }^{5}$

The above brief overview shows that there is a broad consensus among scholars discussing NPM instruments that NPM strives to improve the efficiency of the public sphere by reducing bureaucratic coordination and state property, by the structural transformation of the public sector organizations, by financial and budgetary reforms, and by focusing more on human resource management and other management reforms influencing bureaucratic behavior, as well as by reforms designed to promote a greater focus on citizen needs and citizen participation. The careful reader has probably realized that the reforms advocated by the NPM movement include both systemic and organizational recommendations, and that the consistent application of these measures poses a real challenge to practitioners.

\section{The relationship between the New Public Management and the Magyary Development Programme}

The Magyary Programme contains both systemic (macro-level) and organizational (micro-level) reform proposals. While the systemic reform proposals are generally characterized by a rejection of the NPM philosophy and its instruments, the ideological impact of NPM can be demonstrated on the organizational level. The linkage between the Magyary Programme and the NeoWeberian state concept is best illustrated by the fact that systemic reform proposals are partially based on Weberian elements, while organization level reforms take the neo elements derived from the NPM movement as their starting point. ${ }^{6}$ In addition to specifically mentioning the NeoWeberian concept of the state (Pollitt - Bouckaert 2011), the Magyary Programme lists the key areas that were targeted by the public administration reform proposals made by the EU member states: "enhancement of the efficiency and effectiveness of public administration; downsizing the costs of public administration; increasing the performance of public administration; involvement

5 For other categorizations of the NPM instruments, see Alonso - Clifton - Díaz-Fuentes (2011); Christensen Lægreid (2002); Grüning (2001); Manning - Shepherd - Blum - Laudares (2008); Pollitt - Summa (1997) and Torres (2004).

6 Hajnal - Rosta (2014) rejects that the Hungarian public administration reforms - at local level - follows the Neo-Weberian state concept. 
of citizens; broadening transparency; modernization and integration of IT technologies into administrative work; citizen-friendly administration; citizens' charters" (MPAJ 2011:16). These proposals are all coherent with the NPM philosophy and can be associated with one or another of Hood's (1991) doctrines.

The systemic reform proposals made in the Magyary Programme - of which a stronger centralisation has already been implemented in the case of background institutions, ${ }^{7}$ as shown by Table 3 - are in line with international trends in terms of the international administrative reorganisations in the wake of the economic crisis (Jun 2009). One consequence of the economic crisis was the spread of centralisation even in countries with a good NPM record.

Table 3. Changes in the organizational structure of public administration

\begin{tabular}{|l|c|c|}
\hline Organization type & $\begin{array}{c}\text { Number in } \\
2010\end{array}$ & $\begin{array}{c}\text { Number in } \\
2011\end{array}$ \\
\hline Ministries & 13 & 8 \\
\hline Organs with national-wide competencies & 45 & 47 \\
\hline Deconcentrated / territorial state administration organs & 292 & 93 \\
\hline Public service providers & 193 & 92 \\
\hline $\begin{array}{l}\text { Foundations and public foundations created by the } \\
\text { government and the ministries }\end{array}$ & 68 & 21 \\
\hline Public companies & 38 & 57 \\
\hline Total & 649 & 318 \\
\hline
\end{tabular}

Source: MPAJ (2011: 24)

In addition to being coherent with international trends, it must also be noted that the "anti-NPM type" measures (Hajnal 2011: 67) introduced during the restructuring of the Hungarian public

$7 \quad$ Foundations and public foundations are one case in point. Version 12.0 of the Magyary Programme reveals that 28 of the 60 public foundations were terminated without a legal successor, while 12 were merged with business associations. Only 20 public foundations were retained, all with a changed staff (MPAJ 2012:22). These steps are in line with Kornai's (2012: 576) statement that after 2010 there is a "merger mania" in Hungary. 
administration system were not and are not driven by any political ideology. Hajnal (2011) has demonstrated that the socialist second Gyurcsány government, coming into office in 2006, merged several agencies with a larger autonomy as well. An overview of the Magyary Programme and the already implemented structural changes in public administration clearly show that the conservative second Orbán government has merely accelerated and broadened this process. ${ }^{8}$ The level of centralization implemented by the Hungarian government is significantly higher than the correction measures introduced in Western-Europe as a response to the crisis to balance off the impacts of the far reaching decentralization of NPM. The centralization steps of the Hungarian public administration reforms had an impact on all levels and almost all organizational units of public administration. Kornai (2012, pp. 50-51) describes the approach of the Orbán government as follows: "Wherever a problem is perceived, the panacea is to centralize and amalgamate. [...] All the changes listed point in a clearly perceptible direction: they reinforce centralization. I term this strong, radical, clearly observable and dizzyingly rapid process of transformation as a centralizing tendency."

Table 4 presents the recommended measurers within the intervention area of the Magyary Programme focusing on organizational structures, their relationship with the NPM approach as well as their expected political objectives and impacts.

Table 4. Relationship between the proposals and recommended measures for organizational restructuring in the Magyary Programme and the NPM

8 To date, the systemic restructuring outlined in the Magyary Programme has already been implemented, while the introduction of organization level changes is slower. One possible explanation is that systemic reforms can be principally blocked on the political level: however, the government's two-thirds majority in Parliament and the power relations in the political arena have ensured that the government does not face and does not have to deal with political resistance. In contrast, the implementation of organizational level reforms, including the application of NPM instruments, is not simply a question of political will, but calls for the active contribution of public servants to ensure its success. This might pose a serious obstacle because the cultural values promoted by NPM and the cultural attitudes characterizing Hungarian society are far less compatible than in the UK, New Zealand and the US. For the institutional determinateness of NPM, see Schedler and Proeller (2007). 


\begin{tabular}{|c|c|}
\hline $\begin{array}{l}\text { Reform proposals compatible with the } \\
\text { NPM philosophy }\end{array}$ & Reform proposals incompatible with the NPM philosophy \\
\hline $\begin{array}{l}\text { Creation of the National Development } \\
\text { Government Committee - separation of } \\
\text { decision-making and execution }\end{array}$ & $\begin{array}{l}\text { Creation of the National Development Government } \\
\text { Committee - strong centralization of competencies under the } \\
\text { Prime Minister's Office }\end{array}$ \\
\hline $\begin{array}{l}\text { Compatible with Schedler and Proeller's } \\
(2002) \text { organizational restructuring } \\
\text { category and Hood's (1991) first doctrine }\end{array}$ & $\begin{array}{l}\text { Incompatible with Schedler and Proeller's (2002) } \\
\text { organizational restructuring category and Hood's (1991) } \\
\text { fourth doctrine }\end{array}$ \\
\hline $\begin{array}{l}\text { Delegation of competencies and tasks from } \\
\text { the county level to the district level during } \\
\text { the creation of administrative districts - } \\
\text { the executive level is closer to citizens } \\
\text { Compatible with Schedler and Proeller's } \\
\begin{array}{l}\text { (2002) organizational restructuring } \\
\text { category and Hood's (1991) fourth } \\
\text { doctrine }\end{array}\end{array}$ & $\begin{array}{l}\begin{array}{l}\text { Centralization of tasks from the local government level to } \\
\text { district } \\
\text { the }\end{array} \\
\begin{array}{l}\text { Incompatible with Schedler and Proeller's } \\
\text { (2002) } \\
\text { organizational restructuring category and Hood's (1991) } \\
\text { fourth doctrine }\end{array}\end{array}$ \\
\hline \multirow[t]{4}{*}{$\begin{array}{l}\text { Greater integration of IT as part of the } \\
\text { Ereky Programme } \\
\text { Compatible with Schedler and Proeller's } \\
\text { (2002) management instruments category } \\
\text { and Hood's (1991) fifth doctrine }\end{array}$} & $\begin{array}{l}\text { Introduction of so-called summit ministries } \\
\begin{array}{l}\text { Incompatible with Schedler and Proeller's (2002) } \\
\text { organizational restructuring category and Hood's (1991) } \\
\text { forth doctrine }\end{array}\end{array}$ \\
\hline & $\begin{array}{l}\text { Centralization towards the central public administration } \\
\text { (state administration) from all other levels of the public } \\
\text { administration (regional, county, micro-regional, local } \\
\text { governments.) Examples: } \\
\text { Transferring of regional development agencies into state } \\
\text { ownership } \\
\text { Integration of professional municipal fire brigades into the } \\
\text { organization of the National Directorate General for Disaster } \\
\text { Management } \\
\text { Incompatible with Schedler and Proeller's (2002) } \\
\text { organizational restructuring category and Hood's (1991) } \\
\text { fourth doctrine }\end{array}$ \\
\hline & $\begin{array}{l}\text { Proposals for simplification and standardization on the } \\
\text { middle management level through the creation of a single } \\
\text { sectoral office responsible for middle management in each } \\
\text { sector after the system's consolidation is completed (MPAJ } \\
\text { 2012:20) } \\
\begin{array}{l}\text { Incompatible with Schedler - Proeller's } \\
\text { organizational restructuring category and Hood's (1991) } \\
\text { fourth doctrine }\end{array}\end{array}$ \\
\hline & $\begin{array}{l}\text { Termination or merging of organizations in the case of the } \\
\text { background institutions of the central administration } \\
\text { Examples: } \\
\text { 1. Merging of the Judicial Service of the Ministry of Public } \\
\text { Administration and Justice, the Asset Management Centre of } \\
\text { the Ministry of Public Administration and Justice, the } \\
\text { Wekerle Sándor Asset Manager, The National Institute for } \\
\text { Public Administration and the ECOSTAT Governmental }\end{array}$ \\
\hline
\end{tabular}




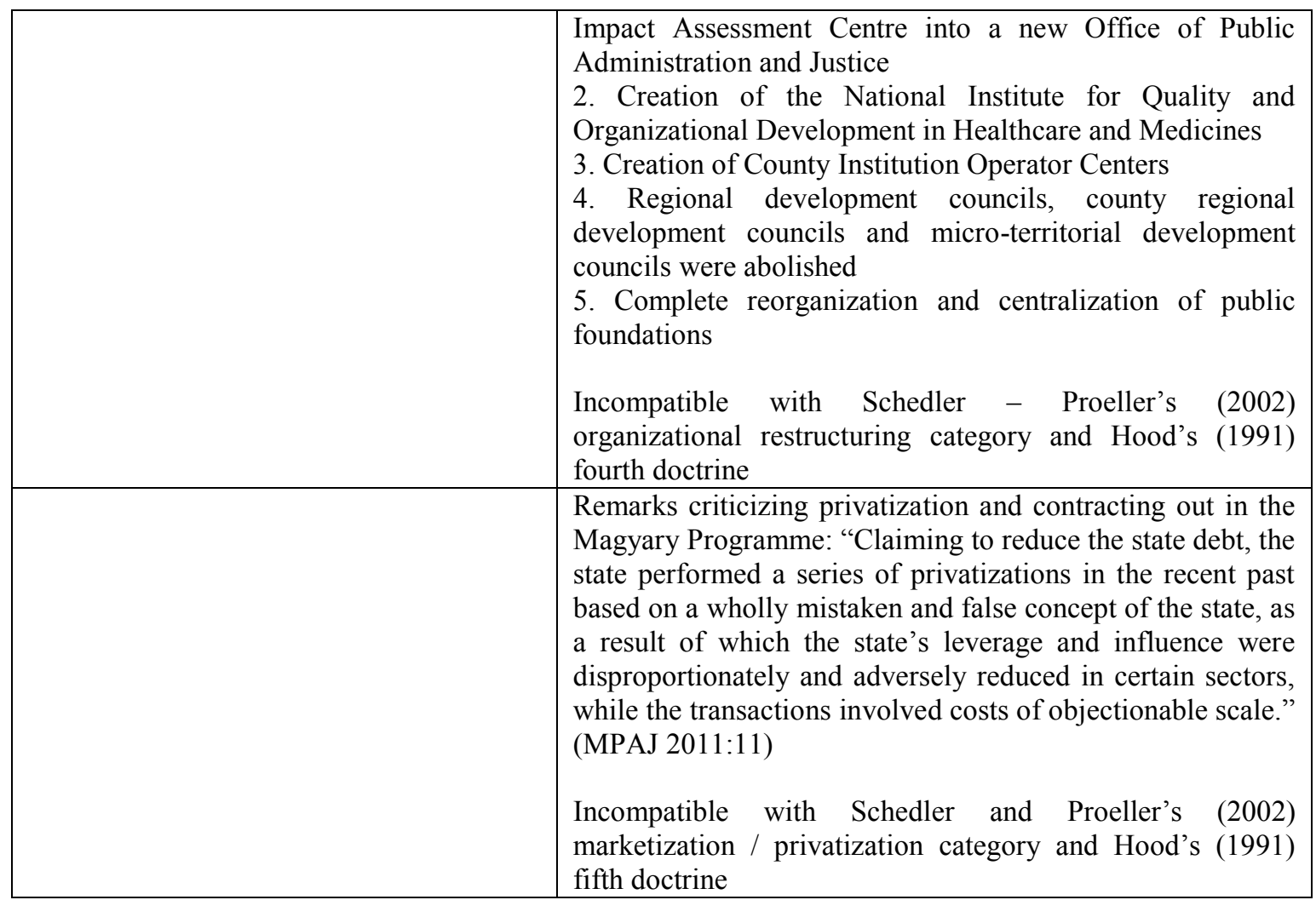

Source: MPAJ (2011) and MPAJ (2012)

Table 4 indicates that most of the systemic reform proposals set down in the Magyary Programme run counter to the values promoted by the NPM movement. The Magyary Programme seeks for a strongly centralized public administration system. The perhaps most salient difference between the NPM philosophy and the approach of the Magyary Programme is that NPM advocates confidence in the civil servants' professional expertise and competence and believes that politicians are capable of adequately monitoring a decentralized public administration and hence bureaucrats' activities are in favor of the needs and interests of the citizens. The essence of the NPM philosophy is the separation of politicians responsible for political decisions, who have the final word on what to do, and of public servants responsible for execution, who can decide on how to achieve the set goals. The systemic reforms outlined in the Magyary Programme would suggest that its authors believe that a public administration with stronger ties to the central government has a greater professional competence and/or stronger loyalties to politicians than public servants working in decentralized organizations (agencies, local governments). They apparently believe that political decision-makers have greater control over a centralized public administration than over a decentralized one. While the ultimate goal of 
centralization is to increase the efficiency and effectiveness of the administrative system, it is questionable whether the efficiency benefits from centralization exceed the costs of eliminating decentralization. It also remains to be seen whether there will be a synergy or conflict between the systemic and organizational reforms proposed in the programme. ${ }^{9}$

Based on Table 4 not only the relationship between the NPM approach and reform measures connected to the organizational restructuring can be reviewed, but also the objectives and impacts of these steps. As shown in Table 4, the objective of most of the structural reform recommendations is not only to generate financial savings but primarily to increase the influence of political decision makers on the processes of public administration and to enforce their political interests, by making even individual, ad hoc decisions. (Hajnal 2013; Pálné Kovács 2011). The tool for this is a strong centralization of public administration.

Our greatest fear concerning the new public administration system outlined in the Magyary Programme is that there will be no clear split between political decision-makers and the public servants performing the administrative tasks in this strongly centralized system. Moreover it is to be feared that the execution of administrative tasks will be dominated by political power instead of professional arguments and expertise. This would run counter not only to the spirit of NPM, but also to the Weberian ideal.

When analyzing the reasons for the reforms deep interconnections need to be considered, that cannot be subject of a detailed description in the present article. Consequently, only some hypotheses can be formulated to describe the underlying reasons for centralization. The following six hypotheses may be formulated.

1. The governing party, FIDESZ has a centralized structure (Kertész 2012). Important decisions are all made by a small group, led by the party chairman / prime minister Viktor Orbán. A strongly centralized party in terms of structure and decision making procedures tends to establish a similarly centralized public administration system when forming a one-party government.

The problem to which the programme would like to react is well known in the literature; nevertheless the system level solution suggested by the Magyary Programme is not in line with the NPM rather it gives a nice example of New Political Governance (Aucoin 2012:178). 
2. According to Toubeau and Wagner (2013), the extent of decentralization or centralization also depends on the cultural and economic policy approach of a party. FIDESZ, in spite of being a central right conservative party, has a basically left wing, populist economic policy communication, whereas it primarily supports the upper-middle class with their actions (for example the introduction of single rate income tax, giving state support mostly to solvent people having foreign currency-based loans, etc.) Ideologically, however, they are clearly conservative, nationalist, sometimes using anti-EU rhetoric (Pogány 2013). According to the authors, parties in favour of implementing left wing economic policy normally prefer centralization because redistribution can take place with the help of the central state apparatus. Although FIDESZ is not a left wing party, it reallocates financial resources to privileged groups of the society, therefore, it is in their interest to strengthen the central administration. Toubeau and Wagner (2013) state that liberal parties are generally in favour of decentralization because it reinforces the diverse nature of the society whereas right wing parties prefer centralization in order to retain the feeling of national and territorial integrity. Toubeau - Wagner (2013) provide a good basis to understand the centralization efforts of FIDESZ.

3. Another explanation of centralization - beyond the above-mentioned internal structure of the governing party - is that the intellectuals supporting FIDESZ do not consider the replacement of the elite groups that took place at the time of the transition sufficient and they still seem to be insulted by this. (G. Fodor - Kern, 2009: 65-66; Ripp 2010). Reasons for the lack of the replacement of the elite include the peaceful nature of the transition and the absence of a revolution. It is not accidental that according to FIDESZ communication, their electoral win was a "revolution"; it paved the way for the significant personal changes that took place in the public sector and to a certain degree in the business sector when they took power. The main characteristic of revolution is that the previous elite are destroyed and new elite emerge; this is taking place now, in course of the Hungarian public administration restructuring.

4. The centralization of the Hungarian public administration is in line with the Leader Democracy model described by Körösényi (2005); it reflects a clearly defined idea of democracy. Based on Weber and Schumpeter, Körösényi (2005:360) states: "The Leader 
Democracy is a minimalist concept of democracy that is skeptical of the feasibility of democracy in the sense of self-rule by the people". The view of human nature and the conceptualization of democracy, which the Leader Democracy model is based on, have a strong impact on the actions of the Hungarian government. This elitist attitude is reflected in the centralization of the decision making, in the course of which every major decision is made by the Prime Minister or by persons or institutions close to him. A political leader such as Viktor Orbán is described by Max Weber as "charismatic" or by Burns as "transformative"; which is in compliance with the characteristics of a political leader described by Körösényi (2005:377), who describes him as being independent from ethical, scientific or societal limitations, only enforcing political aspects in his decisions. This interpretation of democracy was also close to Margaret Thatcher, Orbán's political role model (Pakulski - Higley 2008).

5. With the centralization efforts, the Orbán government intended to increase the power of the Hungarian state, because, in his opinion, in order to address market failures that had emerged after the transition, a strong central state is necessary. As Hutchcroft (2001: 28) states quoting Fesler (1968), the introduction of the system of the county level government offices and government commissioners are actually a step in this direction: "The single most effective strategy of centralizing rulers was prefectoralism, a system by which 'the national government divides the country into areas and places a prefect in charge of each' (Fesler 1968: 374). Fesler explains that the prefect 'represents the whole government, and all specialized field agents in the area are under his supervision' (1968, 374)". Fesler's description is fully applicable for the Hungarian county government offices.

6. Centralization is the government's response to the economic crisis ('t Hart et al. 1993; Peters 2011). According to 't Hart et al. (1993:12) governments tend to respond to a crisis with strong centralization. As stated by the authors, it means the following: "First, it may refer to the concentration of power in the hands of a limited number of executives. Second, it may involve the concentration of decisional power with the central government vis-à-vis state, regional, or local agencies. Third, it may pertain to the tendency, under critical circumstances, to look for strong leadership and embrace one or another form of crisis 
government" ('t Hart et al. 1993:12). As shown in Table 4, the Hungarian government applies all three forms of decision making centralization.

Table 5 shows the linkage between the proposals of the Magyary Programme affecting processes and the NPM movement.

Table 5. Relationship between the proposals and recommended measures for tasks and processes in the Magyary Programme and the NPM

\begin{tabular}{|c|c|}
\hline Reform proposals compatible with the NPM philosophy & $\begin{array}{c}\text { Reform proposals } \\
\text { incompatible with the NPM } \\
\text { philosophy }\end{array}$ \\
\hline $\begin{array}{l}\text { "Direct involvement of citizens in the creation of customer-friendly and efficient } \\
\text { processes." (MPAJ 2011:8) } \\
\text { Compatible with Schedler and Proeller's (2002) customer orientation/quality } \\
\text { management category }\end{array}$ & \\
\hline $\begin{array}{l}\text { "The proliferation of state organizations and the tangled mesh of unclear } \\
\text { responsibilities are not only inefficient, but also one of the main causes of } \\
\text { corruption." (MPAJ 2011:9) } \\
\text { Compatible with Schedler and Proeller's (2002) organizational restructuring } \\
\text { category and Hood's (1991) first and fourth doctrine }\end{array}$ & \\
\hline $\begin{array}{l}\text { Efficient and transparent management of tasks and the designation of the individual } \\
\text { responsible for a particular task (MPAJ, 2011:29) } \\
\text { Compatible with Schedler and Proeller's (2002) management instruments category } \\
\text { and Hood's (1991) first and fourth doctrine }\end{array}$ & \\
\hline $\begin{array}{l}\text { Separation of decision-making / purchasing and executive tasks associated with } \\
\text { individual tasks (MPAJ 2011:31) } \\
\text { Compatible with Schedler and Proeller's (2002) organizational restructuring } \\
\text { category and Hood's (1991) fourth doctrine }\end{array}$ & \\
\hline $\begin{array}{l}\text { Uniform strategic planning in public administration (MPAJ 2011:34) } \\
\text { Compatible with Schedler and Proeller's (2002) management instruments category } \\
\text { and Hood's (1991) first and fourth doctrine }\end{array}$ & \\
\hline $\begin{array}{l}\text { "The widespread integration of IT is undeniably one of the most important means of } \\
\text { improving the efficiency of public administration. The broadening of e-government } \\
\text { services and the improvement of their quality is an important part of the Magyary } \\
\text { Programme" (MPAJ 2011:36) } \\
\text { Compatible with Schedler and Proeller's (2002) management instruments category } \\
\text { and Hood's (1991) sixth doctrine }\end{array}$ & $\begin{array}{l}\text { "in this case too [IT } \\
\text { integration], we must strive } \\
\text { for the greatest possible } \\
\text { centralization within the } \\
\text { framework provided by the } \\
\text { reliable operation of the } \\
\text { systems, with an IT staff } \\
\text { made up of public servants } \\
\text { who have taken the oath; } \\
\text { the purchase of any other } \\
\text { personnel services can only } \\
\text { be ancillary in this field" } \\
\text { (MPAJ 2011:36) }\end{array}$ \\
\hline
\end{tabular}




\begin{tabular}{|c|c|}
\hline & $\begin{array}{l}\text { Incompatible with Schedler } \\
\text { and Proeller's (2002) } \\
\text { marketization } \\
\text { privatization category and } \\
\begin{array}{l}\text { Hood's (1991) fifth } \\
\text { doctrine }\end{array}\end{array}$ \\
\hline $\begin{array}{l}\text { "the simplification of unclear procedures and processes ... is vital " (MPAJ 2011:36) } \\
\text { Compatible with Schedler and Proeller's (2002) organization restructuring category } \\
\text { and Hood's (1991) sixth doctrine }\end{array}$ & \\
\hline $\begin{array}{l}\text { "It is crucial that personal responsibility be continuously identifiable both in task } \\
\text { setting and in the processes that must be drastically simplified for exactly this } \\
\text { reason." (MPAJ 2011:37) } \\
\text { Compatible with Schedler and Proeller's (2002) management instruments category } \\
\text { and Hood's (1991) second and fourth doctrine }\end{array}$ & \\
\hline $\begin{array}{l}\text { "Creating well-functioning processes and providing good quality services is } \\
\text { insufficient for regaining the trust of the citizens and of social and economic } \\
\text { organizations. If these actors are not involved in the planning of the services they are } \\
\text { entitled to and in the decision-making affecting them, their confidence in public } \\
\text { administration will not grow. Taking international best practice as a starting point, } \\
\text { the goal of the Magyary Programme is that public administration should take the } \\
\text { initiative in communicating with the people, and to encourage their active } \\
\text { participation in the state's activities." (MPAJ 2011:37) } \\
\text { Compatible with Schedler and Proeller's (2002) participation/partnership category } \\
\text { This point cannot be linked to Hood's (1991) doctrines }\end{array}$ & \\
\hline $\begin{array}{l}\text { Introduction of a Code of Ethics (MPAJ 2012:47) } \\
\text { Compatible with Schedler and Proeller's (2002) customer orientation/quality } \\
\text { management category } \\
\text { This point cannot be linked to Hood's (1991) doctrines }\end{array}$ & \\
\hline
\end{tabular}

Source: MPAJ (2011) and MPAJ (2012)

Table 5 reveals that in contrast to the systemic reforms outlined in the programme, the reform proposals for the organization of tasks and processes within an organization are in line with the proposals and attitudes embodied by NPM. The involvement of citizens in decision-making and maximizing customer satisfaction is defined as an important priority. One of the programme's goals is to make the public administration system and the activity of public servant transparent and accountable. It adopts the international best practice (e.g., Code of Ethics) and various management techniques used in the private sector (e.g., strategic planning, greater IT integration). The emphasis on personal responsibility and the creation of a system of controls suggests that the authors of Magyary Programme have accepted the viewpoint of the public 
choice theory, therefore making efforts to monitor public servants to ensure that instead of pursuing their own interests, their activities focus on public good, i.e. the interest of the citizens.

Table 6 shows the relationship between the proposals and recommended measures for procedures in the Magyary Programme and the NPM philosophy.

Table 6. Relationship between the proposals and recommended measures for procedures in the Magyary Programme and the NPM philosophy

\begin{tabular}{|c|c|}
\hline Reform proposals compatible with the NPM philosophy & $\begin{array}{l}\text { Reform proposals } \\
\text { incompatible with the } \\
\text { NPM philosophy }\end{array}$ \\
\hline $\begin{array}{l}\text { Reliable and predictable procedures (MPAJ 2011:38) } \\
\text { Compatible with Schedler and Proeller's (2002) organizational restructuring category } \\
\text { and Hood's (1991) sixth doctrine }\end{array}$ & \\
\hline $\begin{array}{l}\text { Standardized procedures, determination of service levels and standards (MPAJ 2011:38) } \\
\text { Compatible with Schedler and Proeller's (2002) organizational restructuring and } \\
\text { management instruments categories and Hood's (1991) sixth doctrine }\end{array}$ & \\
\hline $\begin{array}{l}\text { Continuous monitoring to ensure that the determined service level is kept (MPAJ } \\
2011: 38) \\
\text { Compatible with Schedler and Proeller's (2002) management instruments category and } \\
\text { Hood's (1991) sixth and seventh doctrine }\end{array}$ & \\
\hline $\begin{array}{l}\text { Creation of an impact analysis system (MPAJ 2011:40; MPAJ 2012:54) } \\
\text { Compatible with Schedler and Proeller's (2002) management instruments category and } \\
\text { Hood's (1991) seventh doctrine }\end{array}$ & \\
\hline $\begin{array}{l}\text { "The goal of the Magyary Programme is the elaboration - on the basis of a standardized } \\
\text { methodology - of the annual work plan, action plan and reports of the ministries, the } \\
\text { creation and maintenance of a central monitoring system of the sectoral and } \\
\text { organizational indicators, and the survey and development of the ministries' data } \\
\text { collection systems and databases." (MPAJ 2011:40) } \\
\text { Compatible with Schedler and Proeller's (2002) management instruments category and } \\
\text { Hood's (1991) third doctrine }\end{array}$ & \\
\hline $\begin{array}{l}\text { "The goal of the Magyar Programme is the creation of customer-oriented service } \\
\text { operations taking account of the needs and interests of customers, the simplification of } \\
\text { procedures, the reduction of civil administrative burdens and the development of high } \\
\text { quality services accessible to all." (MPAJ 2011:41) } \\
\text { Compatible with Schedler and Proeller's (2002) customer orientation and quality } \\
\text { management categories } \\
\text { This point cannot be linked to Hood's (1991) doctrines }\end{array}$ & \\
\hline
\end{tabular}




\begin{tabular}{|l|l|}
\hline $\begin{array}{l}\text { "budget proposals in public administration should be prepared on a costs/revenues basis, } \\
\text { instead of on earlier budget bases, in an ideal case using the activity-based costing" } \\
\text { (MPAJ 2011:41) }\end{array}$ & \\
$\begin{array}{l}\text { Compatible with Schedler and Proeller's (2002) budgetary reforms category and Hood's } \\
\text { (1991) sixth doctrine }\end{array}$ & \\
\hline Application of LEAN and BPR methods (MPAJ 2012:52) & \\
$\begin{array}{l}\text { Compatible with Schedler and Proeller's (2002) management instruments category and } \\
\text { Hood's (1991) sixth doctrine }\end{array}$ & \\
\hline $\begin{array}{l}\text { System-level implementation of CAF (MPAJ 2012:53) } \\
\text { Compatible with Schedler and Proeller's (2002) management instruments and customer } \\
\text { orientation/quality management categories and Hood's (1991) third and sixth doctrines }\end{array}$ & \\
\hline $\begin{array}{l}\text { Development of one-stop shops - government windows (MPAJ 2012:55) } \\
\text { Compatible with Schedler and Proeller's (2002) management instruments category } \\
\text { This point cannot be linked to Hood's (1991) doctrines }\end{array}$ & \\
\hline
\end{tabular}

Source: MPAJ (2011) and MPAJ (2012)

Table 6 shows strong linkage between the procedures outlined in the Magyary programme and the NPM: almost every organizational level recommendation and instrument of NPM appears in the programme. One of the goals set down in the programme is the use of budgeting procedures recommended by the NPM movement. For example, the introduction of performance budgeting (or accrual accounting) instead of cameralistic accounting would represent a significant advance in Hungary's public administration. Proposals for the determination of service levels and standards by which the quality of public services can be measured can likewise be linked to the NPM movement. The time when the strategic and operative planning cycle of Hungarian public administration can be linked and unified using balanced scorecard does not seem too far away in the light of the proposals made in this section of the Magyary Programme.

Obviously, the question remains whether the plans outlined in the programme will be put into practice, which proposals will be accepted by decision-makers and which decisions will be executed by public servants. Our fears are based on Pollitt's (2007:14) contention that there is considerably more talk about NPM reforms (discursive convergence) than actual political decisions made about their introduction (decisional convergence), while the number of NPM reforms implemented and accepted by public servants is even less (operational convergence). One of the potential dangers of the Magyary Programme is that the systemic reform proposals, 
whose introduction seems straightforward from a change management and organizational sociological perspective, will be implemented or have in part already been put into practice, while the programme's organizational level proposals - affecting processes, procedures and staff - will falter on the indifference of politicians and run up against the resistance of the public administration organizations.

Finally, Table 7 shows the linkage between the reform proposals concerning human resources and the NPM philosophy.

Table 7. Relationship between the proposals and recommendations for human resource management in the Magyary Programme and the NPM

\begin{tabular}{|c|c|}
\hline Reform proposals compatible with the NPM philosophy & $\begin{array}{l}\text { Reform proposals } \\
\text { incompatible with the } \\
\text { NPM philosophy }\end{array}$ \\
\hline $\begin{array}{l}\text { Creation of a so called "employer matrix", i.e. a uniform framework for } \\
\text { coordinating and organising work (MPAJ 2011:44) } \\
\text { Compatible with Schedler and Proeller's (2002) management instruments category } \\
\text { and Hood's (1991) first doctrine }\end{array}$ & \\
\hline $\begin{array}{l}\text { Consideration of efficiency and performance during the creation of a career path } \\
\text { model (MPAJ 2011:43) } \\
\text { Compatible with Schedler and Proeller's (2002) management instruments category } \\
\text { and Hood's (1991) first and third doctrines }\end{array}$ & \\
\hline $\begin{array}{l}\text { "Professional expertise ('he or she knows') - appropriate selection, continuous } \\
\text { training and the improvement of abilities and capabilities." (MPAJ 2011:44) } \\
\text { Compatible with Schedler and Proeller's (2002) management instruments category } \\
\text { and Hood's (1991) first doctrine }\end{array}$ & \\
\hline $\begin{array}{l}\text { "Trust ('let them do') - necessary executive power with (material and professional) } \\
\text { support from leaders, colleagues and customers." (MPAJ 2011:44) } \\
\text { Compatible with Schedler and Proeller's (2002) organizational restructuring } \\
\text { category and Hood's (1991) first doctrine }\end{array}$ & \\
\hline $\begin{array}{l}\text { Introduction of the HAY method for evaluation the scope of activities (MPAJ } \\
2012: 65) \\
\text { Compatible with Schedler and Proeller's (2002) management instruments category } \\
\text { and Hood's (1991) first doctrine }\end{array}$ & \\
\hline $\begin{array}{l}\text { Introduction of a performance evaluation system (MPAJ 2012:67) } \\
\text { Compatible with Schedler and Proeller's (2002) management instruments category } \\
\text { and Hood's (1991) third doctrine }\end{array}$ & \\
\hline
\end{tabular}

Source: MPAJ (2011) and MPAJ (2012) 
The proposals for human resource management (HRM) set down in the Magyary Programme comply with the techniques current in the business world and are designed to enhance the efficiency of the public administration staff. Surveying the recommendations of the Magyary Programme, it is clear, that the authors of the programme have studied the HRM reforms introduced in Hungary and have clearly learnt from the mistakes made in the past. One case in point is the proposal for a performance assessment system, which will simplify the procedure and ensure more frequent feedback. However, it does not seem too promising that the performance assessment system is predominantly based on job descriptions because most of the tasks specified in these descriptions are obviously performed by public servants and thus a differentiation between the performances of individual public servants will run into difficulties. ${ }^{10}$ However, the goal of the system is exactly to reward good performers and set them as examples, and to call attention to bad performers in order that both they and other public servants learn from their mistakes. An individual-based performance assessment system will only be effective if the salary of good performers is increased and if excellent performance serves as a model for the public administration staff. The Magyary Programme does not mention the objective performance indicators against which the performance of public servants is to be measured, perhaps because its authors did not wish to enter into these details, despite the fact that it is exactly these finer details that will determine whether the system will be feasible in the long run or whether its introduction will fail. It would be crucial to know whether the proposal refers to different performance indicators for different organizational levels (both horizontally and vertically), because the higher a position in the hierarchy, the more performance indicators should be linked to the organization's goals, while the lower a position, the more these indicators should be linked to specific tasks. Although the Magyary Programme does not enter into details, the planned performance assessment system should promote (1) a better understanding and acceptance by public servants of organizational goals, (2) the long-term development of the organization's staff, (3) the acceptance of the organization's achievements by the staff, as well as of its consequences for their remuneration and their promotion, and finally (4) the better understanding of the organization's achievements by the broader public.

\footnotetext{
10 Version 12.0 of the Magyary Programme, however, claims that performance assessment will not be exclusively based on job descriptions, but on other criteria as well (MPAJ 2012: 66).
} 
In addition to employing various NPM instruments, the Magyary Programme shows a commitment to downsizing the Hungarian public administration system by setting the goal of decreasing the number of public servants and filling up their ranks with young professionals. A smaller state is not synonymous with a weaker state: the consistent centralization on the systemic level, one of the obvious goals of the programme's creators, is also apparent in HRM. Therefore the following new units have been created expressly for HRM: a Strategic Centre in the Ministry of Public Administration and Justice, a Methodological Centre based on the Office of Public Administration and Justice, a chamber-like organization called Self-Esteem Centre (in effect, a National Body of Government Servants) and, finally, a Training Centre as part of the National Public Service University (MPAJ 2012:59). Although the separation of various tasks is in line with the NPM philosophy, the strong centralization efforts appearing in the proposal and the corporatist attitude of the National Body of Government Servants is incompatible with NPM.

\section{Conclusions}

The objective of the study was to describe the main characteristics of the Hungarian public administration reform, to highlight the inconstancies of their elements and to draw attention the related risks. The reform recommendations set out in the basic document of the reform was compared with the ideal type NPM approach. Following a brief overview of the values and attitudes promoted by the NPM movement, as well as of NPM instruments, we offered a detailed analysis of the four so-called "intervention areas" in public administration discussed in the Magyary Programme. The macro level recommendations of the programme were analyzed in detail; it clearly set the objective of strengthening the central state administration, primarily through strong centralization. The level of centralization introduced by the Orbán government is significantly higher than the level of centralization implemented in the Western-European public administration systems as a response to the economic crisis. The possible reasons were also demonstrated; (1) the strongly centralized organizational structure and operation of the governmental party, (2) the cultural and economic policy attitude of FIDESZ, (3) the desire of the intellectuals supporting FIDESZ to replace the elite groups that did not take place at the time of the transition, (4) the prime minister's and the his allies' views on human nature and their approach of democracy, (5) the need to increase the power of the state and finally (6) the impact of the economic crises were described as possible reasons for centralization. In the case of 
organizational level reforms not only the reform measures were described but also the context of the reforms.

Based on the study we can state that the macro level reform recommendations reject the NPM philosophy, various NPM instruments are used on the organizational level and that the programme adopts the basic NPM attitudes on this level. Although this study did not seek to evaluate the Magyary Programme, it does offer an assessment of some of its proposals and recommendations, and it also points out a few potential sources of danger that might sabotage the programme's goals. The greatest perils that the organizational reforms implemented by the current Hungarian government do not only contradict the principals of the NPM approach, but also, they over-centralize the Hungarian public administration system. This over-centralization is the main reason for the significant contradictions between the various areas of intervention of the Magyary Programme which might hinder the implementation of the micro level reform recommendations.

\section{References}

Alonso, J. M. - Clifton, J. - Díaz-Fuentes, D. (2011): Did New Public Management matter? An empirical analysis of the outsourcing and decentralization effects on public sector size. COCOPS Working Paper 4.

Arellano-Gault, D. (2010): Economic-NPM and the need to bring justice and equity back to the debate on public organizations. Administration \& Society 42(5): 591-612.

Aucoin, A. (2012): New Political Governance in Westminster systems: Impartial public administration and management performance at risk. Governance 25(2): 177-199.

Bach, S. - Bordogna, L. (2011): Varieties of New Public Management or alternative models? The reform of public service employment relations in industrialized democracies. International Journal of Human Resource Management 22(11): 2281-2294.

Bao, G. - Wang, X. - Larsen, G. L. - Morgan, D. F. (2013): Beyond New Public Governance: A Value-Based Global Framework for Performance Management, Governance, and Leadership. Administration \& Society 45(4): 443-467.

Barzelay, M. (2001): The New Public Management. Improving research and policy dialogue. Berkeley, CA: University of California Press. 
Borins, S. (2002): New Public Management, North American style. In: K. McLaughlin, S. P. Osborne - E. Ferlie (Eds.): New Public Management: Current trends and future prospects (pp. 181-194). New York, NY: Routledge.

Boston, J. (2011): Basic NPM ideas and their development. In: T. Christensen - P. Lægreid (Eds.): The Ashgate Research Companion to New Public Management (pp. 17-32). Farnham: Ashgate Publishing Limited.

Box, R. C. - Marshall, G. S. - Reed, B. J. - Reed, C. M. (2001): New Public Management and substantive democracy. Public Administration Review 61(5): 608-619.

Christensen, T. - Lægreid, P. (2002): New Public Management: Puzzles of democracy and the influence of citizens. The Journal of Political Philosophy 10(3): 267-295.

Christensen, T. - Lægreid, P (Eds.) (2011): The Ashgate Research Companion to New Public Management. Farnham: Ashgate Publishing Limited.

Fesler, J. W. (1968): Centralization and decentralization. In: Sills D.L. (Ed.): International encyclopedia of the social sciences (Vol. 2, pp. 370-379). New York, NY: Macmillan.

G. Fodor, G. - Kern, T. (2009): A rendszerváltás válsága. [The crisis of the regime change.]. Budapest: Századvég Kiadó.

Greve, C. - Hodge, G. (2011): A transformative perspective on public-private partnerships. In: T. Christensen - P. Lægreid (Eds.): The Ashgate Research Companion to New Public Management (pp. 265-80). Farnham: Ashgate Publishing Limited.

Grüning, G. (2001): Origin and theoretical basis of New Public Management. International Public Management Journal 4(1): 1-25.

Hajnal, G. (2011): Adminisztratív politika a 2000-es évtizedben. Az ügynökség-típusú államigazgatási szervek strukturális dinamikája 2002 és 2009 között. [Administrative Politics in the Decade of 2000. The Structural Dynamics of the Organs of Public Administration of Agency Type between 2002 and 2009.]. Politikatudományi Szemle 20(3): 54-74.

Hajnal, G. (2013): Public sector reform in Hungary: views and experiences from senior executives. Country report as part of the COCOPS research project.

Hajnal, G. - Rosta, M. (2014): The illiberal state on the local level. The doctrinal foundations of subnational governance reforms in Hungary (2010-2014). Working Papers in Political Science 2014/1. 
Haynes, P. (2011): The return of New Public Management? Working Paper SSRN.

Hood, C. (1991): A public management for all seasons? Public Administration 69(1): 3-19.

Hood, C. (2007): Public service management by numbers: Why does it vary? Where has it come from? What are the gaps and the puzzles? Public Money - Management 27(2): 95-102.

Hutchcroft, P. D. (2001): Centralization and decentralization in administration and politics: assessing territorial dimensions of authority and power. Governance 14(1): 23-53.

Jun, J. S. (2009): The limits of Post-New Public Management and beyond. Public Administration Review 69(1): 161-165.

Kertész, K. (2012): Hogyan mérjük a pártok centralizáltságának fokát? [How to measure the degree of Parties' centralisation?]. XXI. század Tudományos Közlemények 28.

Kornai, J. (2012): Centralization and the capitalist market economy in Hungary. CESifo Forum 13(4): 47-59.

Körösényi, A. (2005): Political Representation in Leader Democracy. Government and Opposition 40(3): 358-378.

Kuhlmann, S. (2010): New Public Management for the 'classical continental European administration': Modernization at the local level in Germany, France and Italy. Public Administration 88(4): 1116-1130.

Lapsley, I. (2009): New Public Management: The cruellest invention of the human spirit? Abacus 45(1): 1-21.

Lapsley, I. (2010): New Public Management in the global financial crisis - dead, alive, or born again? Working Paper presented at IRSPM Conference. Berne, Switzerland, 6-9 April.

Lengyel, G. - Ilonszki, G. (2012): Simulated democracy and pseudo-transformational leadership in Hungary. Historical Social Research 37(1): 1-20.

Manning, N. (2001): The legacy of the New Public Management in developing countries. International Review of Administrative Sciences 67(2): 297-312.

Manning, N. - Shepherd, G. - Blum J. - Laudares, H. (2008): Public management reform: Should Latin America learn from the OECD? OECD.

McLaughlin, K. - Osborne, S. P. - Ferlie, E. (Eds.) (2002): New Public Management: current trends and future prospects. New York, NY: Routledge.

Ministry of Public Administration and Justice [MPAJ] (2011): Magyary Zoltán Közigazgatásfejlesztési Program (MP. 11.0). A Haza üdvére és a Köz szolgálatában. [Magyary Zoltán 
Public administration development Programme (MP. 11.0) For the salvation of the nation and in the service of the public]. Budapest. http://magyaryprogram.kormany.hu/admin/download/8/34/40000/Magyary-Kozigazgatasfejlesztesi-Program.pdf, accessed 27 March 2015.

Ministry of Public Administration and Justice [MPAJ] (2012): Magyary Zoltán Public administration development Programme (MP 12.0). For the salvation of the nation and in the service of the public. http://magyaryprogram.kormany.hu/admin/download/a/15/50000/Magyary kozig fejlesztesi program_2012_A4_eng_\%283\%29.pdf, accessed 27 March 2015.

Moynihan, D. P. (2006): Ambiguity in policy lessons: The agencification experience. Public Administration 84(4): 1029-1050.

OECD (1995): Governance in transition. Public management reforms in OECD countries. Paris: OECD.

Ongaro, E. (2009): Public management reform and modernization. Trajectories of administrative change in Italy, France, Greece, Portugal and Spain. Cheltenham: Edward Elgar.

Osborne, D. - Gaebler, T. (1992). Reinventing Government: How the entrepreneurial spirit is transforming the public sector. Reading, MA: Addison- Welsey.

Pakulski, J. - Higley, J. (2008): Towards Leader Democracy? In: ‘t Hart, P. and Uhr, J. (eds.): Public Leadership: Perspectives and Practices (pp. 45-56). Canberra: ANU E Press.

Pallesen, T. (2011): Privatization. In: T. Christensen - P. Lægreid (Eds.): The Ashgate Research Companion to New Public Management (pp. 251-64). Farnham: Ashgate Publishing Limited.

Pálné Kovács, I. (2011): Local Governance in Hungary - the Balance of the Last 20 Years (Discussion Papers 2011/83). Pécs: Centre for Regional Studies of the Hungarian Academy of Sciences.

Peters, B. G. (2011): Governance responses to the fiscal crisis - comparative perspectives. Public Money \& Management 31(1): 75-80.

Peters, B. G. - Pierre, J. - Randma-Liiv, T. (2011): Global financial crisis, public administration and governance: Do new problems require new solutions? Public Organization Review 11(1): 13-27. 
Pogány, I. (2013): The crisis of democracy in East Central Europe: the 'New Constitutionalism' in Hungary. European Public Law 19(2): 341-367.

Pollitt, C. (1995): Justification by works or by faith: Evaluating the New Public Management. Evaluation 1(2): 133-154.

Pollitt, C. (2002): Clarifying convergence. Striking similarities and durable differences in public management reform. Public Management Review 4(1): 471-492.

Pollitt, C. (2005): Performance management in practice: A comparative study of executive agencies. Journal of Public Administration Research and Theory 16(1): 25-44.

Pollitt, C. (2007): Convergence or divergence: What has been happening in Europe? In: C. Pollitt, C., S. van Thiel - V. Homburg (Eds.): New Public Management in Europe. Adaptation and alternatives (pp. 10-25). New York, NY: Palgrave Macmillan.

Pollitt, C. - Summa, H. (1997): Trajectories of reform: Public management change in four countries. Public Money - Management 17(1): 7-18.

Pollitt, C. - van Thiel, S. - Homburg, V. (Eds.). (2007): New Public Management in Europe. Adaptation and alternatives. New York, NY: Palgrave Macmillan Publishing.

Pollitt, C. - Bouckaert, G. (2011): Public management reform: A comparative analysis. New Public Management, governance and the Neo-Weberian State. Oxford, UK: Oxford University Press.

Ripp, Z. (2010): Egy szürke eminenciás színeváltozásai [The transfiguration of an éminence grise]. Mozgó Világ 36.

Schedler, K. - Proeller, I. (2002): The New Public Management. A perspective from mainland Europe. In: K. McLaughlin, S. P. Osborne - E. Ferlie (Eds.): New Public Management: current trends and future prospects (pp. 163-180). New York, NY: Routledge.

Schedler, K. - Proeller, I. (Eds.). (2007): Cultural aspects of public management reform. Oxford: Emerald Insight

Siltala, J. (2013): New Public Management: The evidence-based worst practice? Administration \& Society 45(4): 468-493.

't Hart, P., Rosenthal, U. - Kouzmin, A. (1993): Crisis decision making: The centralization thesis revisited. Administration \& Society 25(1): 12-45.

Torres, L. (2004): Trajectories in public administration reforms in European Continental countries. Australian Journal of Public Administration 63(3): 99-112. 
Toubeau, S. - Wagner, M. (2013): Explaining party positions on decentralization. British Journal of Political Science 45(1): 97-119.

Van de Walle, S. - Hammerschmid, G. (2011): Coordinating for cohesion in the public sector of the future. COCOPS Working Paper 1.

Walker, R. M. - Brewer, G. A. - Boyne, G. A. - Avellaneda, C. N. (2011): Market Orientation and Public Service Performance: New Public Management Gone Mad? Public Administration Review 71(5): 707-717.

Zavattaro, S. M. (2013): Management movements and phases of the image: Potential for closing the loop. Administration \& Society 45(1): 97-118. 